\title{
CHRISTIANITY AND ECOLOGY A CRITICAL STUDY ON THE CONTRIBUTION OF SDA THEOLOGY TOWARD ECOLOGY
}

\author{
M Rizal Abdi and Ferry Goodman Pardamean Pardosi \\ Center for Religious and Cross-cultural Studies \\ Graduate School of Universitas Gadjah Mada \\ Email: m.rizal.a@mail.ugm.ac.id
}

\begin{abstract}
ABSTRAK
Sampai saat ini, publikasi artikel kontroversial dari Lynn White Jr, The Historical Roots of Our Ecological Crisis (1967) menyulut perdebatan sengit antara teolog dan akademisi di bidang agama dan ekologi tentang dosa Kekristenan Barat terhadap bencana ekologis modern. Sementara itu, sebagai denominasi Kristen yang sangat menekankan pada Kedatangan Kedua (Advent) dan kehidupan setelah kematian, doktrin Seventh-Day Adventist (SDA) Church sering dituduh sebagai alasan mengapa doktrin kekristenan cenderung mengesampingkan masalah lingkungan saat ini dan lebih terfokus pada kehidupan berikutnya yang kekal. Meskipun, pada saat bersamaan, SDA Church juga dikenal karena penekanannya pada kehidupan holistik sekaligus menjadi salah satu gereja paling maju dalam ilmu kesehatan dan kedokteran. Dengan segala kritik dan praduga tersebut, penelitian ini justru mencoba untuk menantang persepsi umum tentang kekristenan dan ekologi langsung di jantung kritiknya. Dengan metodologi penelitian berbasis pustaka (literature based research), tulisan ini menelaah doktrin SDA Church dalam konteks ekologi sekaligus menunjukkan bagaimana SDA Church mewujudkan doktrin ekologisnya. Lebih lanjut, pada diskursus yang lebih luas tentang agama dan ekologi, eksplorasi pada teologi SDA menunjukkan bahwa alih-alih menjadi sumber masalah, doktrin eskatologis bisa menjadi faktor pendorong praktik ekologis dewasa ini.
\end{abstract}

Kata Kunci: Seventh-Day Adventist Church; Eskatologi; Ekologi; Sabat; Sanktuari

\section{ABSTRACT}

To date, the controversial publication of Lynn White Jr's article, The Historical Roots of Our Ecological Crisis (1967) ignites the fierce debate between theologian and academia in the field of religion and ecology about the guilt of Western Christianity toward modern ecological calamity. Meanwhile, as a Christian denomination that highly emphasizes on the second coming (the Advent) and the next life, Seventh-Day Adventist (SDA) Church doctrine is frequently accused as the reason why Christianity doctrine tend to put aside today's environmental problem and more focused in the eternal next life. Though, at the same time, SDA Church also known for its emphasis on holistic life as well as one of the most advanced church in health and medical science. Given those handicap, the research tries to challenge those common perceptions about Christianity and ecology right into the heart of its criticism. By using literature-based research as methodology, this paper scrutinizes the doctrine of SDA church within the context of ecology as well as demonstrates how the SDA Church manifests its ecological doctrines. Furthermore, on wider discourse of religion and ecology, the explorations on SDA theology shows that rather than becoming a source of problem, the eschatological doctrine might become the driven-factor toward ecological practices nowadays.

Keywords: Seventh-Day Adventist Church; Eschatology; Ecology; Sabbath; Sanctuary 


\section{INTRODUCTION}

Since the publication of Lynn White Jr.'s controversial yet influential article, The Historical Roots of Our Ecologic Crisis (1967), has been continuously debated by the theologian and academia in the field of Religion and Ecology. White Jr. argued out that our ecological calamities nowadays are the fruit of our ecological attitudes which rooted on our religious belief. Specifically, White pointed out Christianity in its Western form becomes the culprit of our ecological crisis. Created from the image of God, man is separated from nature and has privilege to exploit nature for his proper ends. This biblical justification opens the path for nature destruction by human and changes Christianity into, "the most anthropocentric religion the world has seen (White, 1967: 1203)." Moreover, the eschatological characteristic of Christianity also contributes on why theologian and many religious people give more credit to life after death instead of present days. Alas, rather than perceived it as self-critics toward Christianity, many Christian's articles-especially in the earlier years-misunderstood one of the White Jr.'s theses as reductionist view and hasty accusation of biblical narration. One of the famous critics is from Al Gore, former vice president of United States. Al Gore argued that White's argument and any biblical justification toward nature exploitation is missing the theological points of the Genesis stories (Al Gore, 1992: 128). On the contrary, $\mathrm{Al}$ Gore saw the biblical narrative of creation as positive force in conserving the environments though he also underlined that the core of our environmental crisis is in spirituality. Put aside White Jr.'s real intention and its counter-argument, Lynn White Jr.'s article undeniably ignites more lively and broad spectrum of interdisciplinary discussion to which degree religion has responsibility to the environmental changes and vice versa.

Responding to the Lynn White's argument as well as the debates and accusations around it, this research explores the contribution of Christianity theology, particularly the one that emphasize on later life than present day, toward ecology. Does the eschatological point of view necessarily put today's ecological problem out of question? Or to put it in another way, how much the eschatological point of view contributes to solve our ecological problem nowadays? Furthermore, this research is also trying to put the discussion of eschatology on the wider discourse of religion and ecology.

In doing so, we examined the doctrine and practices of Seventh Day Adventist (SDA), one of the Christianity denominations, related to ecology. There are, at least, three reasons why we choose SDA as our case study. First, as church denominations, SDA was established on 1863 in United States of America which have strong presence as the form of Western Christianity. As shown in White's argument, since the medieval period Western Christianity plays significant role in ecological calamity by the extensive use the technology to extort the natural resources as a manifestation of Old Testament mandate to "subdue" the earth (Whitney, 2015:402). Second, as its name suggest, one of the SDA doctrines highly emphasizes on the second coming (the Advent) and the next life. This eschatological doctrine is frequently accused as the reason why Christianity tend to put aside today's environmental problem and more focused in the eternal next life.

Third, even though the SDA church is known for its emphasis on diet and health as well as "holistic" understanding of the person, the discussion about SDA and ecology is rarely elaborated. SDA Church promotes the endorsement of healthful living as one of the religious obligation and part of Godgiven responsibility (Kuhalampi, 2010:240). However, for decades, the discussion on ecology and environment is mostly absent in SDA church's view though the healthy environment is also become requirement to the healthful living. On broader aspect of Christianity literature, the discussion about SDA and ecology is mostly absent in many major and well-known publication about religion and ecology (Hessel \& Ruether, 2000; Gottlieb, 2006; Jenkins, Tucker, \& Grim, 2016). 
Therefore, there has been very little research done on the eschatological doctrine of Christianity toward ecology, let alone the denominations that strongly emphasize on the doctrine, for example SDA Church.

\section{Ecology in SDA Eschatology}

As its name suggest, SDA Church is Protestant Christian denominations that distinguished by its observance of Saturdayalso known as Sabbath, the seventh day of the week in Christian and Jewish calendars, and by its emphasis on the imminent Second Coming (advent) of Jesus Christ (Queen, Prothero, and Shattuck, 2009:913; Kulahampi, 2015:11). Unlike majority of Christian church, SDA church continue to uphold the tradition of Sabbath as have been obliged in Ten Commandment. Thus, during the Sabbath, Adventists avoid secular work other than medical relief and humanitarian work and gather for church services on Saturday morning or Friday night.

Other distinctive characteristic of SDA is the eschatological doctrine of Second Coming Jesus Christ. Everything in Adventism is fashioned by eschatology (Gutierrez, 2018). Adventist believes that Jesus will come to the Earth for the second time on Sabbath after the global crisis. During Jesus' return, the righteous will be taken to heaven for a millennium while the rest will be annihilated after a millennium. Unlike the traditional doctrine, hell is not the eternal place for punishment. Finally, God will create a new Earth as a place for the righteous to live eternally without $\sin$ and suffering. This eschatological doctrine is uniquely upheld by the Adventist.

At a glance, the doctrines put more weight on the next life where the SecondComing happen rather than present time. This understanding is visible in the very name of Adventism, which means "coming," "arrival," to earnestly wait for Jesus' second coming (Gutierrez, 2018). Within this framework, the eschatology tends to ignore ecological calamity that continue to happen until nowadays. According to the doctrine, the Second-Coming will be preceded by Global
Crisis on Earth and in the end will be annihilated together with the unrighteous. For extend, the ecological calamity that lead to Global Crisis might become catalyst for the Second-Coming. Thus, this eschatological point of view is unproductive for our ecological problem.

Given those handicap, the research tries to challenge those common perceptions about Christianity and ecology right into the heart of its criticism. By using literature-based research as methodology, this paper scrutinizes the doctrine of SDA church within the context of ecology as well as demonstrates how the SDA Church manifests its ecological doctrines.

\section{DISCUSSION}

Through the explorations on SDA theology, this research aims to show that eschatology doctrine does not necessarily ignore today's ecology. In fact, as shown later, many valuable insights from doctrines and practices can be drawn to respond our environmental problem todays. In doing so, the discussion starts with the examinations of the official statement from SDA Church. The statement lays foundations on how the church perceives and tackles the ecological problem on doctrinal and practical level.

\section{Three Official Environmental Statements of SDA Church}

As global institutions, SDA church publishes three official statements related to the environmental and ecology. The first one was in 1992 entitled Caring for Creation: A Statement on the Environment which emphasized the world as a gift of love form a Creator God and the Sabbath as a memorial of God's creative act. Furthermore, the 1992 statement also highlighted that human decision to disobey God by breaking the original order of creation cause the environmental degradation. Hence, recognizing the interrelatedness of environmental degradation and quality of life, the 1992 statement promoted sustainable development of resources while meeting human needs. 
The second statement was A Statement on the Environment published in 1995. Even though human was created in the image of God, and thus, "representing God as His stewards, to rule the natural environment ...", their corrupt and over-exploitation behavior toward nature are involved in the megalomaniacal destruction of Earth's resources which resulting in widespread human suffering. The 1995 statement literally stated that, "the ecological crisis is rooted in humankind's greed and refusal to practice good and faithful stewardship within the divine boundaries of creation." Thus, Adventists were urged to lead, "a simple, wholesome lifestyle ... showing respect for creation and exercising restraint in the use of the world's resources." Compared to the first, the second statement clearly pointed out specific human's behavior as the root of ecological crisis and advocated particular way of life in order to hold back the degradation of nature.

The third statement was published a year later in 1996 in San Jose, Costa Rica entitled A Statement on Stewardship of the Environment. Briefly, this statement emphasized that the same points as the second statement and even most of the words and sentence in second statement were re-used in the third one. The third statement particularly commended the government and people of Costa Rica for their support of a comprehensive policy of sustainable development in harmony with nature which implies that governments were being called to action - not only church entities or members.

All of the statements were issued during 90 's decade when the matter of ozone leak-out and global warming became wide-public discussion around the world. During 90's, many Christian denominations declared statements in global level to show their concerns for the planet, some of the notable documents were "Peace with God the Creator, Peace with All of Creation" (1990) from Roman Catholic and "Mennonite Statement on the Environment: Poverty and Environmental Degradation" (1990) from Mennonite Central Committee. Though the statements had been issued two decades after White's controversial publication, the actions showed that the silence of global religious institutions, Christianity particularly, was no longer an option. Furthermore, the statements also ignited more discussion both on theologians and laid people on how the religion might contribute in facing the ecological calamity.

\section{The SDA Church's Doctrine on Ecology: From Sabbath to Sanctuary}

The three SDA church's statements have become the main sources and references for many literatures on SDA and ecology. There is not much SDA article discussed on ecology before the statements have been issued. One of the few was from Harwood A. Lockton entitled "The Neglected Message of the Creation Story", which published on Ministry. Vol. 64. Sep 1991: 9-11. Reflecting from the vulnerability and fragility of the earth, Lockton stressed out on how many Adventist and Christian in general, used the creation doctrine as a basis for propositional truth but had been largely neglected its relational and ethical aspects. Lockton started his argument by presenting paradox message on Genesis 1 and 2. Tracing the same root of the word "economy", "ecology, and "stewardship", Lockton argues that "the earth was given to us in the sense of leasehold, not freehold (Lockton, 1991:9)." It implies that human are only custodians in that land and everything inside it. Furthermore, Lockton also proposed another way to see the Genesis message through the call of Sabbath in which we, "turn aside from six days of our work to think of God's work (Lockton, 1991:10)". By doing so, as Lockton remarked, human might have opportunity to escape from the materialistic pressures as well as perpetual reminder that God also wished to liberate us from those. In other words, the Genesis message not only told about the meaning of our origin but also manifested the world nowadays.

At the same year with the first SDA official statements, Lockton also published his article, "Seeing Green Adventists and the Environment", on Dialogue (College and Uni- 
versity). Vol. 4. 1992: 5-7. Re-examined the biblical view on environment, Lockton not only revisited the concept of Sabbath but also elaborated four main events of salvation history - the Creation, the Fall, the Redemption, and the Eschaton. By doing so, Lockton underlined three intertwined relations among God, others, and nature as the key concept in responding to the environmental issue. In the Creation, Lockton asserted the dual position of humanity as mentioned in Genesis 1 and 2. Human is created in God's image and thus apart from nature, yet at the same time human also the creations and so are a part of nature. Thus, as Lockton implied, human combine their dependence upon God with dominion over the Earth. Furthermore, the three intertwined relations between God, human, and nature are disrupted at the Fall. More than just breaking spiritual relationship between human and God, the Fall also signified the disrupted relations between humanity and earth which become, "the root of modern humanity's environmental predicament. (Lockton, 1992:6)." Yet, these breaking relations were renewed through the Redemption of Christ. This renewed relationship aspired people to be a better steward of God by taking care the relation between God, human, and environment. Moreover, Lockton elaborated the biblical verse on Revelation to revisit the Eschaton event. Rather than nullifying our responsibility towards environment, the future coming of Jesus in the Judgment Day strengthens our motives to take care of it. As shown in Revelation 11:18, in the end God will destroy those who destroy Earth.

These two main themes-Sabbath and the four main event of Salvation history - become fruitful field for the Adventist scholars to scrutinize the environmental issue and develop their eco-theology. On 1993, Spectrum, the Journal of the Association of Adventist Forum, released a special section consist of five articles in the environmental issues which mostly re-examining those two main themes. Outlining a few of the most ecological challenge, Alvin Kwiram in "Adventists and The Good Earth" (1993) called the Ad- ventist to transform the ecology of their faith in order to respond the scientific challenge of global environment change. Kwiram suggested to expand the established religious metaphor, such as Sabbath by giving greater attention to the holiness of creation as well as to enrich the metaphor by borrowing others tradition perspectives, such as Eastern holism and connectivity or Mother/God dimension (Kwiram, 1993:32-34).

Likewise, reviewing Al Gore's book Earth in the Balance, Roy Benton made a connection for several Gore's themes as well as drew the prophetic message in Old Testament and book of Revelation to connect environmental concerns with distinct SDA tenets, such as Sabbath, love nature, simplicity, holism, and apocalyptic. Benton re-articulated those tenets in modern language in order to echo the message of minor prophet and the book of Revelation. One fine example, when God commanded Noah to take into his ark at least two of every living species, we may translate that message into modern context as: "thou shalt preserve biodiversity" (Benton, 1993: 39).

Meanwhile, "In the Compelling Case of the Nature", Glenn Coe as a lawyer and Adventist argued that nature also has a right to "exist unmolested by humanity (Coe, 1993:36). Yet, Coe took other route to interpret the Genesis narration and also demonstrated that God did not abdicate His ownership of His creation. He cited Psalm 24:1, "The earth is the Lord's" which implied that God own all living things that inhabit the earth. Hence, even though humanity has a higher priority in God's creation than animal or plant life, human are accountable for how they fulfill their responsibility toward God. Practically, Coe suggests that we need to avoid all wastefulness - such as by not using animal skin for bag or wardrobe, using double side of the paper - not only because out of solidarity with the poor, but also out of respect for the living environment (Coe, 1993:37).

Similarly, David. B. J. Trim on his article, "Proclaim Liberty or Submit to Authority", also underlined the requirement to respect 
the world that God created perfect as the biblical basis for civic and ecological activism among Adventist Christians. Drawing the inspirations from Revelation 14:12 as well as the biblical concept of Jubilee, Trim argued that Christians have a threefold level of responsibility: as members of this community; as citizens of our nations; and as members of the body of Christ-the church (2009:11). However, these positions are entangled with our duty as ambassadors on earth who have full responsibility to God in taking care the nature because, as the Third Angel's message in Revelation 14:12, those who perform false religion by destroying the nature would be destroyed by God (Trim, 2009:15).

On the other hand, the Resurrection events became the core subject for Brian $W$. Harper to illuminate the relationship of Christianity to the environmental issue. Rather than perceived as merely historical events, Harper through his work, "The Resurrection of the World (1993)", suggested that the Resurrection are God's ongoing activity to save the world. Similar to Lockton's 1991 article, Harper underlined how many Christians have become caught up in another worldly heaven and forgot that God first called Christians to live in the "here and now" of the world (1993: 41). Everything we know about God, including the symbols that help us to understand Him, are related to our surroundings. In other words, we experience God's spirit on earth (Harper, 1993: 42). Furthermore, according to Harper, the incarnation was an evidence of God's love for the natural environment and His love did not end with the dead of Jesus on the cross. The Resurrection gives the Christians hope that God would never abandon us and this spirit enable us to believe that God will help us through our environmental hazards as nuclear waste, chlorofluorocarbons, and pollution (Harper, 1993:43). Moreover, in Adventist tradition, the Resurrection of Jesus as the High Priest is to bring salvation that extends to the entire universe, not only human being.

The extended salvation towards the universe also becomes Jon Ann Davidson's subject of discourse in his article "Seventh Day Adventist and Ecology" in The Word of God for the People of God (2010). Earlier of his article, Davison described two reasons why SDA Church neglected to link the ecology to our theology. First, some people think that ecological issues were not a critical topic at all since world is going to be burned up soon anyway. Second, the accusation that Christianity has proved uniquely dangers to the environment by abusing the "dominion" that God bestowed on human beings at creation (Davidson, 2010:359). Hence, Davidson argued that the SDA Church should take ecology as a subject that need to be discussed in theology. In doing so, Davidson demonstrated many biblical verses and its modern interpretation as foundation for the church to be actively in the environmental crisis as well as displayed that the plan of salvation is extended towards universe. For example, in the book of Taurat which particularly the book of Deuteronomy 20:19, God instructed His people which was Israeli not to destroy of fruits tree in order to aid a military campaign (Davidson, 2010:360). The contextualization of this instruction in our modern life means it is prohibited for Adventist to brutally destroy the nature even though it's for survival. In the case of Sabbath, as mentioned by the book of Exodus 23:10:12, God instructed His people to have one day full rest after six day of work. Yet, this instruction does not stop to human only but also to animal and vineyard, and thus every people who owned an animal that use for labor should give them rest. Another example comes from the book of Exodus 23 verse 4 and 5 which instruct human to give mercy toward a donkey. One should help donkey to stand when it has fallen under a heavy load, even of the animal belongs to an enemy. Animals need to be treated with compassion like we treat human. Moreover, the message that animal and plant are also part of God's plan of salvation is strengthened by the Genesis 9:9 -which told about God's covenant to human and animal after the global catastrophe flood killed living things in the earth (Davidson, 2010: 363). Furthermore, re- 
flecting from Isaiah 11:6 which gives prophecy of new earth where all creature are laid down to each other, Davidson also stressed that even though we are still living in the sinner earth that stimulus us to treat animal badly, we need also to learn to love the animal as the preparation for us to live in the new earth. In the last part of the article, Davidson proposed the Adventist to change their way of life by having consciousness in recycling everything possible: glass, cans, plastic, batteries, newspapers, phone books, plus using white paper on both sides (2010:373) as well as to revisit vegetarian diet in the light ecological concerns as Ellen White's, one of the founder of SDA church, advice.

As mentioned above, the issue of Sabbath, as one of the special distinctive feature of SDA, has frequently examined yet there are few scholars that focused his work on Sabbath. One of them is Sigve K. Tonstad with his work, The Lost Meaning of the Seventh Day (2009). More than merely a day to worship God, the seventh-day Sabbath is where the human story begins, and it is where, under God, the story will end. Through exegetical and historical analysis, Tonstad argued that the seventh-day Sabbath is a gift from God to all humanity as a celebration of the world God had and continuing to make. The victory of Sunday over Sabbath not only shows the beginning of imperial control instrument but also constructs the church into hierarchy (Tonstad, 2009: 73). In turn, this event ignites the damage and causes the calamity to both the body and the earth.

On the other hand, the discourse of Sanctuary which becomes one of the core teachings of Adventist is measly elaborated. Warren Trenchard in "For the Beauty of the Earth: An Adventist Theology of Ecology" (2003) developed, "an Adventist theology of the earth within a paradigm of five basic affirmations: creation, deterioration, salvation, anticipation, and restoration (Trenchard, 2003:34)." According to Trenchard's interpretation, God is the creator and sustainer of the world and the entire creature within. The deterioration of the world begin when human rebel to God which caused the degradation of the planet and life upon it. In order to restore the calamity, God through Jesus provides salvation to the universe not limited to human being and through Holy Spirit, God anticipates the ultimate restoration where $\mathrm{He}$ will restore the world and the creature within-including human, animal, and plant life-to their perfect state. In brief, Trenchard's interpretation of five events is similar with Lockton's reading on four main Salvation history. Yet, Trenchard move beyond Lockton's idea by perceiving the Sabbath not only as reminder for God's saving attitude toward universe but also as the anticipation of earth's ultimate renewal. Moreover, Trenchard elaborated the Sanctuary doctrine, a true tabernacle which the Lord set up, to the five events to show unbroken and continuous plan of God's love toward nature since the creation process until the eternal live after the ultimate restoration. In addition, Jesus ministry in the heavenly sanctuary symbolizes that every human action to take care for the earth are accountable by God. In other words, the sanctuary doctrine reminds that humanity is fully responsible for their action towards nature.

Similarly, Ashleigh Greaves on "Should Seventh-day Adventists Adopt a Theology on Ecological Preservation" also explicated Sanctuary as theological basis of SDA in their responsibility on ecological carefulness. Initiating with awareness that ecological preservation is existential reality, Greaves called us to revisit our understanding about sanctuary. According to Gen 1.27, after created the humans God gave them dominion over the whole earth and human were responsible for its care. Later, in Genesis 2.19, the first activity that God gave to Adam was to look after the garden in which he was placed. In other words Garden of Eden is in the world and the earth itself is part of sanctuary. Within this light, there would be huge demands to protect the Earth (Greaves, 2004: 7).

Correspondingly, Edward R. Brown in Our Father's World: Mobilizing the Church to Care for Creation (2008) argued that Earth was created as a medium to reveal God as well as 
to provide a place of worship for humans. In other words, earth and the creatures within are the "second" Bible (Brown, 2008:114). Within this framework, if Christians perceive the church pews and carpets as parts of the sanctuary, the natural world surely is a stadium for worship where human have obligation to preserve it.

Throughout the discussion around SDA Church's doctrines above, the Adventist eschatology does not necessarily rule out the present ecological problem. Sabbath and Salvation which lays foundation of SDA Church theological doctrine also become fruitful resources of SDA ecological theology. Similarly, both doctrines emphasize the role of human as God's steward as their core understanding. This framework differentiates the SDA church's eco-theology with other contemporary "green" discourses, such as Pantheism (Hewitt, 2018), Gaia (Lovelock, 2006), Deep Ecology, and Ecofeminism (Mathews, 1994). Rather than positioned human equal with other creatures (as in Pantheism and Deep Ecology) or perceived Earth as living organism (as in Gaia), SDA doctrine perceived human as the image of God who have special position and role towards nature but limited by its relationship to God and nature. In other words, Adventist ecological doctrine tries to walk a course between humanism and pantheism. Human and nature both are God's creature and thus both works as community of beings. However, the special position of human only applied when they serve as a good steward of God's creation.

\section{SDA and the Environmental Practice}

Within the discussion of the environmental practice of SDA, we might categorize the literatures into two categories. First, the works that discussed about personal practice such as the Holistic living and way of life. Second, the literature that examined the social or community practices of SDA for example country living and education institution in health and environmental issue.

\section{Healthy living as part of Environmental Practice}

Within the personal practices category, Ellen White, one of the founders of SDA church, initiated the holistic life as the manifestation of good stewardship toward nature. Through her book Counsel and Diet (1938), White stated intimate relation between the mind and the body. When one is affected, the other sympathizes. The condition of the mind also affects the health of the physical system. If the mind is free and happy, it will react upon the whole system and make the circulation of the blood better that in turn tune up of the entire body. This healing power is blessing from God. Thus, the Lord is not pleased if we don't take care of our body. Furthermore, God also provides us with nature as healing medium which also have God's healing quality (White, 1938:27). Thus, in Ministry of Healing (1905), White said that "although sin has cast its shadow over the earth, God desires His children to find delight in the works of His hands (White, 1938:159)". Thus, within this light, the sick need to be brought into close touch with nature rather than "caged" in closed room.

Furthermore, within the discourse of religion and ecology, Sigve K. Tonstad in "Ecology, Ethics, and Ecumenism" have re-interpreted Ellen White's message and bring her health message into a new level. Nowadays, meat consumption has multiplied in unbelievable numbers, millions of animal were killed every day and it accounts for approximately $25 \%$ of the greenhouse gas emission. Given this situation, Tonstad argued that the traditional Seventh-day Adventist health message - which has done well emphasizing the benefits of a nonmeat diet with regard to cholesterol levels, weight, risk of heart disease, and even cancer-need to be expand to the ethical, ecological, and eco-theological reasons. Instead of healthy reason and necessity, Tonstad asserted that the reason why Ellen White suggested vegetarian way of live is simply because of mercy towards God's non-human creation. Moreover, many verses in bible implies and even clearly states that 
nonhuman creation has already suffer more (Isa.11:9; Rom.8:19-22) and the God's blessing was also pronounced on nonhuman creature (Gen.1:22).

In other article, "Swine of the Times: Ecumenism, Ecology, and Ethics in the Era of Factory Farming", published on Spektrum Vol. 37(2009), Tonstad saw that the ecological crisis open the opportunities to rebuilt better understanding foundation toward nature and God. He proposed six attempts in order to build on the twin foundations of creation and the eschaton (2009:19). Most of the proposals related to shifting our framework from caused responsive action to narrative motivated practice. Thus, the practice of non-vegetarian and non-eating pig or meat would shift to practice of loving animal and non-human creature.

This point of view is strengthened with his interview on "What are we Really Doing towards God's Creature (2010)". Tonstad reflected from the Genesis story and stressed that the first blessing ever was a blessing on nonhuman creation, and blessing for human came later and follow the wording of God's blessing on nonhuman creation. It implies that nonhuman creation also has legitimacy from God and human should honor and respect their older-brother/sister-in-blessing. Furthermore, Tonstad proposed eco-theology paradigm which put ecology under the umbrella of theology. By doing so, He tried to revisit the motivation of Christian, or particularly Adventist, in "going green". Rather than moved by the headline of the newspaper or the consequences of environmental problem, Tonstad argued that ecological and health practice of Adventist should be inspired and anchored by the narrative of human interconnectedness with nature and God.

\section{Developing Educational Institution}

Remarkably, the attempt to become good stewardship of God as well as the obligation to perform holistic life also manifests on the eagerness and enthusiasm of SDA to develop educational institution in the field of health, medicine, and environment. Floyd E. Hayes and William K. Hayes in "Seventh-Day Adventist Faith and Environmental Stewardship" show the logic behind this enthusiasm. Adventists regard the human body as "a temple of the Holy Spirit" (1 Corinthians 6:19) and strive to balance the physical, mental, and spiritual aspects of human nature through conformity with God's moral and natural laws (Hayes \& Hayes, 2011:4). Furthermore, in practical level, influenced by Ellen White's writings, Adventists have historically emphasized the study of nature as God's "second book" (Hayes \& Hayes, 2011:5). "God's great book of nature is open for us to study, and from it we are to gain more exalted ideas of His greatness and unexcelled love and glory" (White, 1958:26). Thus, most Adventist colleges and universities offer an introductory course on the environment as well as develop integrated education on health and environment which started from the level elementary school up to doctoral degree. Hayes and Hayes demonstrated how the $7^{\text {th }}$ and $8^{\text {th }}$ grade students of SDA school already conducted research on ecology and pollution around their region (2011:7). Furthermore, as shown by Hayes and Hayes, many SDA members actively involved in research on environmental and biodiversity issues, even in not-so-popular-field such as the studies of obscure microorganisms, plants, animals, and ecosystems. They believe that the environmental arena can bring together the two, often-polarized field study-science and religion-for a common good (Hayes \& Hayes, 2011:8).

\section{Country Living}

Meanwhile, in community level, country living practice becomes the manifestation of SDA teaching. The origin of the teaching of country living in SDA could be traced from Ellen White's book, Country Living (1946), which compiled from her writing after she died. One of the cause of environmental crises according to scientist is over population which caused by the urbanization. According to White, the limited resources on the city created problem in the city such as corrup- 
tion, crime, and many the record of violencrobberies, murders, suicides, and crimes unnamable (1946:1). Hence, White stated that city living is not God's plan and called people to leave the city and live in the village.

Other than perceiving city life as false, artificial, and opening the door to a thousand evils, White remarked that the physical surroundings in the cities are often a peril to health. The constant liability to contact with disease, the prevalence of foul air, impure water, impure food, the crowded, dark, unhealthful dwellings, are some of the many evils to be met (White:1946:2). Hence, she concluded that it was not God's purpose that people should be crowded into cities, huddled together in terraces and tenements (1946:3). To live in the country would be very beneficial to people because an active, outof-door life would develop health of both mind and body. White liked to stress the important of living with garden and cultivating the soil until she argued that the great Master Himself blessed the work of tilling the soil (1946:17). Tilling the soil is one of the God's way to make His people understand that $\mathrm{He}$ loves them very much. If we see tilling the soil with one view, we can conclude that it is part of the curse, but actually it is a blessing for human so we can see how God grows the corps that we plant. We have to notice that leaving the city into the country side is not like asceticism which separate themself from the world and do not involve with worldly business. White said that we have to leave the cities but we must work in the cities but not dwell in them like prophet Enoch (1946:28). White also mentioned when church member should live in the country, they need to establish sanitarium, publisher, training center, agriculture industries (1946:29) and other that will bring a blessing to other people.

In addition, the SDA commission on $\mathrm{Ru}$ ral Living produced a guide, entitled from City to Country Living, for people who wants to practice country living. Reflected from post-World War II situation, there are massive movements from SDA members to fulfill the call of God by leaving the cities and locat- ing their homes in rural areas. The guide was made to help people to implement the message in the book of Country Living (1950:5). SDA member believes that the instruction and counsel presented in Country Living has been given to them by God. Living in the country will lead the Adventist more harmony with the God's ideal (1950:7) because country is the best place to develop our physical, mental, and spiritual dimension (1950:15). Interestingly, rather than organized or assisted by the church, the responsibility for heading and acting is belong to the members. The adversary and challenge in gaining information and establishing the housing is part of seeking wisdom from the will of God because He has commissioned His spirit to be your counselor and guide (1950:8). Moreover, by cultivating the land and treating the earth as God's treasure house, the SDA manifests their religious teaching in becoming good stewardship on behalf of God. (1950:45).

It is interesting to be noted that though SDA Church global institution have not issued any statement related to ecology since 1996, there are big enthusiasms to actively practice country living among the Adventist nowadays. Compared to country living practice during Ellen White's period, the $21^{\text {st }}$ century country living is driven by eschatological awakening rather than merely healthy living. The abundant information about our ecological problems through various sources has stimulates Adventist to rethink the eschatological linkage on ecological impact of modernity. As Holy Scripture prophecy told, the Second Coming of Jesus (the Advent) will be preceded by the global crisis that affected the whole mankind regardless their countries and races. This understanding generate spiritual enlightenment that manifested through ecological practices, such as country living. Within this frameworks, the practice of country living have two related and inseparable dimensions. It is the obligation to live a healthy life and fulfill the call of faith whether it's in the form of a call to country living as exemplified by Ellen White - as well as preparing for the best conditions to wel- 
come the Second Coming. These context triggers ecological practice in SDA today.

\section{CONCLUSION}

The SDA church does not endorse any unique position on environmental stewardship, but their theological views offer some distinctive perspectives. In fact, SDA church might be categorized as late-comer to the discussion of religion and ecology. Moreover, on the surface level, its position as Western Christianity which emphasized on millennial theology becomes "handicap." Yet, the explorations around the literatures of SDA and ecology demonstrate that many valuable insights from doctrines and practices can be drawn. Officially speaking, as global religious institutions, SDA Church already published three official statements on environmental issues. These official statements became the source of inspirations for the Adventist scholar to dig and revisit their religious doctrine and unique traditions. Most of the discussion in SDA and ecology are revolving around the re-examining of the Sabbath as memorial for God's creation, four main events of the Salvation history, and also the Sanctuary.

However, it should be noted that the motives underlying the practice is changing overtime. In the practical level, we might see that the manifestation of SDA environmental stewardship works in two levels: personal and social or community level, which both of them are highly inspired by Ellen White's teaching. In personal level, SDA encourages the holistic life which perceives the unity and interconnectedness between soul and body. Late Adventist scholar and theologian bring White's teaching into a new level by expanding the spirit of healing and interconnectedness to the environment. In social or community level, the practice of country living represents how the Adventist should manage its three intertwined relations among god, human, and nature. Facing today's global ecological problems, the Adventist revisits their understanding of global crisis that preceded the Second Coming that lead to country living driven by eschatological doctrine rather than healthy living. Moreover, in order to support this particular way of living as well as reflecting from biblical teaching of body and nature as second scripture, the SDA enthusiastically develop the integrated educational institutions in the field of health and environment.

Unfortunately, within the abundant resources on SDA doctrines towards ecology, there is not much literature that discussed about particular case studies in SDA environmental practice. For example, it is hard to find the case studies of country living in SDA community nowadays even though there are SDA communities who continue to practice this tradition. Given this situations, it is hard to see how far the ecological changes have impacted on Adventist religious tradition and vice versa. Moreover, many articles around environment and biodiversity from SDA communities issue are invisible in the lens of religious studies because it is usually categorized in the box of natural science. Even though the SDA scientists believe that environmental issues might become the bridge between religion and science but the researches which embrace both enterprises are hardly found.

\section{BIBLIOGRAPHY}

Benton, Roy. 1993. "Earth in the Balance." Spectrum. Vol.22 no.5. Maryland: Association of Adventist Forum.

Brown, Edward R. 2008. Our Father's World: Mobilizing the Church to Care for Creation. Illinois: Inter-Varsity Press.

Coe, Glenn. 1993. "In the Compelling Case of the Nature". Spectrum. Vol.22 no.5. Maryland: Association of Adventist Forum.

Commission on Rural Living. 1950. From City to Country Living. Review and Herald Publishing Association, Takoma Park, MD.

Davidson, Jon Ann. 2010. "Seventh Day Adventist and Ecology" in The Word of God for the People of God. Review and Herald Publishing Association, Takoma Park, MD. 
Davidson, Jon Ann. 2010. "Seventh Day Adventist and Ecology". The Word of God for the People of God. Herald Publishing.

Gore, Al. 1992. Earth in the Balance: Ecology and the Human Spirit. Boston: Houghton Mifflin.

Gottlieb, Roger S (Ed.). 2006. The Oxford Handbook of Religion and Ecology. Oxford: Oxford University Press.

Greaves, Ashleigh. 2004. Should Seventhday Adventists Adopt a Theology on Ecological Preservation. Thesis. Friedensau University.

Gutierrez, Hanz. 2018. How Healthy Is Adventist Eschatology? An Endogenous Imbalance. Accessed on 23rd August 2018. <https:/ / spectrummagazine.org/ article/2018/05/10/how-healthyadventist-eschatology-endogenousimbalance-part-1>

Harper, Brian W. 1993. "The Resurrection of the World". Spectrum. Vol.22 no.5. Maryland: Association of Adventist Forum.

Hayes, Floyd E. and Hayes, William K. 2011. "Seventh-Day Adventist Faith and Environmental Stewardship". H. T. Goodwin (ed.), Berrien Springs, Michigan: Andrews University Press.

Hessel, Dieter $\mathrm{T}$ and Ruether, Rosemary Radford (Ed.). 2000. Christianity and Ecology: Seeking the Well-Being of Earth and Humans. Harvard: Harvard University Press.

Hewitt, Simon J. 2018. “God is not a person (an argument via pantheism)" . International Journal for Philosophy of Religion. Springer. Downloaded from https://doi.org/10.1007/s11153018-9678-xz

Jenkins, Willis J., Tucker, Mary Evelyn, and Grim, John (Eds.). 2016. Routledge Handbook of Religion and Ecology. London: Routledge
Kuhalampi, Harri. 2010. Holistic Spirituality: In the Thinking of Ellen White. Dissertation, Helsinki: University of Helsinki.

Kwiram, Alvin L. 1993. "Adventists and the Good Earth." Spectrum. Vol. 22. Jan 1993

Lockton, Harwood A. "Seeing Green Adventists and the Environment." Dialogue (College and University). Vol. 4. 1992: 5-7.

Lockton, Harwood A. “The Neglected Message of the Creation Story." Ministry. Vol. 64. Sep 1991: 9-11.

Lovelock, James. 2006. The Revenge of Gaia: Why the Earth Is Fighting Back - and How We Can Still Save Humanity. Santa Barbara (California): Allen Lane.

Mathews, Freya. 1994. "Relating to Nature: Deep Ecology or Ecofeminism?" The Trumpeter: Journal of Ecosophy 11 (4) (Fall): 159-166.

Queen, Edward L.; Prothero, Stephen R.; Shattuck, Gardiner H. 2009. "Seventh-day Adventist Church". Encyclopedia of American religious history. Volume 3 (3rd ed.). New York: Infobase Publishing.

Seventh Day Adventist Church Official Statement. A Statement on Stewardship of the Environment. October 1, 1996. General Conference of Seventh-day Adventists Administrative Committee (ADCOM). San Jose, Costa Rica, October 1.

Seventh Day Adventist Church Official Statement. A Statement on the Environment. June 29, 1995. General Conference of Seventh-day Adventists Administrative Committee (ADCOM). Utrecht, the Netherlands.

Seventh Day Adventist Church Official Statement. Caring for Creation: A Statement on the Environment. October 12, 1992. General Conference of Seventh-day 
Adventists Executive Committee. Silver Spring, Maryland.

Tonstad, Sigve K. 2009. The Lost Meaning of the Seventh Day. Berrien Springs, MI: Andrews University Press.

Tonstad, Sigve. 2009. "'Swine of the Times": Ecumenism, Ecology, and Ethics in the Era of Factory Farming', Spectrum, 37 (2009), 16-22.

Tonstad, Sigve K. 2010. “What are we Really Doing towards God's Creature". Accessed on 20 January $2016<w w w$. adventistreview.org/factoryfarms.>

Tonstad, Sigve K. 2012. “Ecology, Ethics, and Ecumenism". Adventist Review.

Trenchard, Warren. 2003. "For the Beauty of the Earth: An Adventist Theology of Ecology". Spectrum: The Journal of the Association of Adventist Forums 31, No 3 (Summer 2003), 34-45.
Trim, David. 2009. "Proclaim Liberty" or "Submit to Authority"? :The Biblical Basis for Civic and Ecological Activism among Adventist Christians', Spectrum, 37 (2009), 10-15. Maryland: Association of Adventist Forum.

White, E. G. 1905. The Ministry of Healing. Pacific Press Publishing Association, Mountain View, CA.

White, E. G. 1938. Counsels on Diet and Foods. Review and Herald Publishing Association, Takoma Park, MD.

White, E. G. 1958. The Faith I Live By. Review and Herald Publishing Association, Takoma Park, MD.

White, Lynn. 1967. “The Historical Roots of Our Ecological Crisis", Science, 155 (1967), 1203-7.

Whitney, Elspeth. 2015. “Lynn White Jr.'s'The Historical Roots of Our Ecologic Crisis'After 50Years". History Compass13/8 (2015): 396-410. John Willey and Sons. 